\title{
Article
}

Mycosphere

Doi 10.5943/mycosphere/8/10/12

Copyright $(\mathcal{C}$ Guizhou Academy of Agricultural Sciences

\section{Two new species in Fuscosporellaceae from freshwater habitats in Thailand}

\author{
Yang $\mathbf{J}^{1,2}$, Liu JK${ }^{1}$, Hyde $\mathrm{KD}^{2,3,4}$, Jones EBG ${ }^{5}$, Liu $\mathrm{ZY}^{1^{*}}$
}

${ }^{I}$ Guizhou Key Laboratory of Agricultural Biotechnology, Guizhou Academy of Agricultural Sciences, Guiyang 550006, Guizhou, China

${ }^{2}$ Center of Excellence in Fungal Research, Mae Fah Luang University, Chiang Rai 57100, Thailand

${ }^{3}$ Key Laboratory for Plant Diversity and Biogeography of East Asia, Kunming Institute of Botany, Chinese Academy of Science, Kunming 650201, Yunnan, China

${ }^{4}$ World Agroforestry Centre, East and Central Asia, 132 Lanhei Road, Kunming, 650201, Yunnan, China

${ }^{5}$ Department of Entomology and Plant Pathology, Faculty of Agriculture, Chiang Mai University, Huay Keaw Road, Suthep, Muang District, Chiang Mai 50200, Thailand

Yang J, Liu JK, Hyde KD, Jones EBG, Liu ZY 2017 - Two new species in Fuscosporellaceae from freshwater habitats in Thailand. Mycosphere 8(10), 1893-1903, Doi 10.5943/mycosphere/8/10/12

\begin{abstract}
A survey of freshwater fungi in Thailand resulted in the discovery of two new species in Fuscosporellaceae, herein described as Fuscosporella aquatica and Mucispora phangngaensis. Fuscosporella aquatica has sporodochial colonies, irregular ellipsoidal and dark brown conidia with vesicular conidiogenous cells. Mucispora phangngaensis has macronematous, solitary conidiophores with percurrent proliferations and dark brown obovoid conidia. Phylogenetic analysis based on combined LSU and ITS sequence data support their placement in Fuscosporella and Mucispora (Fuscosporellaceae, Fuscosporellales). Both species formed distinct clades from their type species and present as the second species in each genus. Descriptions and illustrations of the new taxa are provided. DNA sequence data of Parafuscosporella mисоsa (from ex-type strain) are provided in this study, and confirmed its phylogenetic placement.
\end{abstract}

Key words - Asexual fungi - Phylogeny - Sordariomycetes - Taxonomy

\section{Introduction}

Fuscosporella was established as a monotypic genus for $F$. pyriformis J. Yang, J. Bhat \& K.D. Hyde, and it is the type genus of Fuscosporellaceae (Yang et al. 2016). Fuscosporella pyriformis is morphologically similar to Parafuscosprella moniliformis J. Yang, J. Bhat \& K.D. Hyde and P. mucosa J. Yang, J. Bhat \& K.D. Hyde, as they share characters such as uniseptate, dark brown, obvoid to obpyriform conidia of similar size, and hyaline vesicular conidiogenous cells. Parafuscosporella garethii Boonyuen, Chuaseehar. \& Somrith. is significantly different from the above species in its obpyramidal conidia, which are coronate at the apex with unusual conical projections (Boonyuen et al. 2016). However, molecular evidence gave a precise classification.

Mucispora was introduced by Yang et al. (2016) as a monotypic genus for M. obscuriseptata J. Yang, J. Bhat \& K.D. Hyde. The genus is characterized by macronematous, mononematous conidiophores, monoblastic, terminal and cylindrical conidiogenous cells and ellipsoidal or obovoid dark brown conidia with three septa. The generic concept of Mucispora resembles Acrogenospora, 
Melanocephala and Monotosporella. Acrogenospora differs from Mucispora in having aseptate conidia (Goh et al. 1998). Melanocephala is specific in its cupulate proliferating conidiogenous cells and its conidia bearing a central downwardly directed collar with a fimbriate margin (Hughes 1979, Wu \& Zhuang 2005). Monotosporella is distinguished from Mucispora by its cylindrical, doliiform or lageniform conidiogenous cells (Sadowski et al. 2012).

During the survey of freshwater fungi on submerged wood along a north / south gradient in the Asian / Australasian region (Hyde et al. 2016), two new freshwater taxa were collected. Phylogenetic analyses of combined LSU and ITS sequence data and morphological characters strongly support the separation of the new taxa in Fuscosporella and Mucispora respectively. We therefore introduce Fuscosporella aquatica and Mucispora phangngaensis as new species, with an illustrated account and phylogenetic evidence.

\section{Materials \& Methods}

\section{Collection and examination of specimens}

Specimens of submerged, decaying wood were collected from stream in Phang Nga Province, Thailand, in December 2015. Specimens were brought to the laboratory in plastic bags and incubated in plastic boxes lined with moistened tissue paper at room temperature for one week. Morphological observations were made using a Motic SMZ 168 Series dissecting microscope for fungal structures on natural substrate. The fungal structures were collected using a syringe needle and transferred to a small drop of distilled water on a clean slide with cover glass. The fungi were examined using a Nikon ECLIPSE 80i compound microscope and photographed with a Canon $600 \mathrm{D}$ digital camera fitted to the microscope. Measurements were made with the Tarosoft (R) Image Frame Work program and images used for figures were processed with Adobe Photoshop CS6 software. Single spore isolations were made onto potato dextrose agar (PDA) or water agar (WA) and later transferred onto malt extract agar (MEA) or PDA following the method of Chomnunti et al. (2014). Specimens (dry wood with fungal material) are deposited in the herbarium of Mae Fah Luang University (MFLU), Chiang Rai, Thailand and Guizhou Academic of Agriculture Sciences (GZAAS), China. Axenic cultures are deposited in Mae Fah Luang University Culture Collection (MFLUCC) and Guizhou Culture Collection (GZCC). Facesoffungi and Index Fungorum numbers are registered as outlined in Jayasiri et al. (2015) and Index Fungorum (2017).

\section{DNA extraction, PCR amplification and sequencing}

Isolates were grown on PDA/MEA medium at $25{ }^{\circ} \mathrm{C}$ for one month. Fungal mycelium was scraped off and transferred to a $1.5-\mathrm{mL}$ microcentrifuge tube using a sterilized lancet for genomic DNA extraction. A Biospin Fungus Genomic DNA Extraction Kit (BioFluxR, Hangzhou, P. R. China) was used to extract DNA following the manufacturer's instructions. LSU and ITS gene regions were amplified using the primer pairs LROR/LR5 and ITS5/ITS4 (White et al. 1990). The amplifications were performed in a $25 \mu \mathrm{L}$ reaction volume containing $9.5 \mu \mathrm{L} \mathrm{ddH}_{2} \mathrm{O}, 12.5 \mu \mathrm{L} 2 \times$ PCR Master Mix (TIANGEN Co., China), $1 \mu \mathrm{L}$ of DNA template and $1 \mu \mathrm{L}$ of each primer (10 $\mu \mathrm{M})$. The amplification condition consisted of initial denaturation at $94{ }^{\circ} \mathrm{C}$ for $3 \mathrm{~min}$; followed by 40 cycles of $45 \mathrm{~s}$ at $94{ }^{\circ} \mathrm{C}, 50 \mathrm{~s}$ at $56{ }^{\circ} \mathrm{C}$ and $1 \mathrm{~min}$ at $72{ }^{\circ} \mathrm{C}$, and a final extension period of $10 \mathrm{~min}$ at $72{ }^{\circ} \mathrm{C}$. Purification and sequencing of PCR products were carried out using the above-mentioned PCR primers at Invitrogen Biotechnology Co., China.

\section{Phylogenetic analyses}

The taxa included in the phylogenetic analyses were selected and obtained from previous studies and GenBank (Maharachchikumbura et al. 2015, 2016, Réblová et al. 2016, Yang et al. 2016). LSU and ITS gene regions were used for the combined sequence data analyses. Sequences were optimized manually to allow maximum alignment and maximum sequence similarity. The sequences were aligned using the online multiple alignment program MAFFT v.7 
(http://mafft.cbrc.jp/alignment/server/) (Katoh \& Standley 2013). The alignments were checked visually and improved manually where necessary.

Phylogenetic analysis of the sequence data consisted of maximum likelihood (ML) using RAxML-HPC v.8 (Stamatakis 2006, Stamatakis et al. 2008) on the XSEDE Teragrid of the CIPRES science Gateway (https://www.phylo.org) (Miller et al. 2010) with rapid bootstrap analysis, followed by 1000 bootstrap replicates. The final tree was selected among suboptimal trees from each run by comparing likelihood scores under the GTRGAMMA substitution model.

Maximum-parsimony (MP) analyses were performed using the heuristic search option with 1000 random taxa addition and tree bisection and reconnection (TBR) as the branchswapping algorithm. All characters were unordered and of equal weight and gaps were treated as missing data. Maxtrees were unlimited, branches of zero length were collapsed and all multiple, equally parsimonious trees were saved. Clade stability was assessed using a bootstrap (BT) analysis with 1000 replicates, each with 10 replicates of random stepwise addition of taxa (Hillis \& Bull 1993).

The program MrModeltest2 v. 2.3 (Nylander 2008) was used to infer the appropriate substitution model that would best fit the model of DNA evolution for the combined datasets for Bayesian inference analysis with GTR+G+I substitution model selected. Posterior probabilities (PP) (Rannala \& Yang 1996, Zhaxybayeva \& Gogarten 2002) were determined by Markov Chain Monte Carlo sampling (BMCMC) in MrBayes v. $3.0 b 4$ (Huelsenbeck \& Ronquist 2001). Six simultaneous Markov chains were run for 1 million generations, with trees sampled every 100 generations. The first 2500 trees, representing the burn-in phase of the analyses, were discarded and the remaining trees were used for calculating posterior probabilities (PP) in the majority rule consensus tree (Larget \& Simon 1999).

The resulting trees were printed with FigTree v. 1.4 .0 (http://tree.bio.ed.ac.uk/software/figtree/), and the layout was created in Microsoft PowerPoint for Mac v. 15.19.1. The alignment of phylogenetic analyses was deposited in TreeBASE (21782). Sequences generated in this study are deposited in GenBank (Table 1).

\section{Phylogenetic results}

The analyzed dataset consisted of combined LSU (1192 bp) and ITS (792 bp) sequence data (a total of 1984 characters including gaps after alignment) for 51 taxa in Sordariomycetes with Microglossum rufum and Leotia lubrica as the outgroup taxa. The best scoring RAxML tree is shown in Fig. 1.

Phylogenetic trees obtained from ML, MP and Bayesian analyses yielded trees with similar overall topology at the order and family levels which are in agreement with previous studies (Boonyuen et al. 2016, Réblová et al. 2016, Yang et al. 2016). Fuscosporella aquatica (MFLUCC 16-0859) clustered together with the type species F. pyriformis (MFLUCC 16-0570), and present as phylogenetically distinct species. Mucispora phangngaensis (MFLUCC 16-0865) and $M$. obscuriseptata (MFLUCC 15-0618) formed a distinct clade which represents Mucispora in Fuscosporellaceae, and the two isolates are phylogenetically distinct. The newly generated sequence data of Parafuscosporella mucosa (from ex-type strain) proved its placement in Parafuscosporella.

\section{Taxonomy}

Fuscosporella aquatica J. Yang \& K.D. Hyde, sp. nov.

Fig. 2

Index Fungorum number: IF553967; Facesoffungi number: FoF03863

Etymology - named for its aquatic habitat.

Saprobic on decaying submerged twigs. Colonies on natural substrate sporodochial, scattered, black. Mycelium partly immersed, partly superficial, composed of septate, hyaline hyphae. Conidiophores macronematous, mononematous, hyaline, smooth-walled, 25-60 × 3-7 $\mu \mathrm{m}$. Conidiogenous cells monoblastic, integrated, terminal, globose, subglobose, ellipsoidal or clavate, hyaline, $17.5-44 \times 10-19 \mu \mathrm{m}(\overline{\mathrm{x}}=28 \times 14 \mu \mathrm{m}, \mathrm{n}=15)$, sometimes guttulate. Conidia acrogenous, 
ellipsoidal or slightly irregular shaped, $38-60 \times 25.5-37 \mu \mathrm{m}(\overline{\mathrm{x}}=48.5 \times 30.5 \mu \mathrm{m}, \mathrm{n}=40)$, dark brown to black, smooth, with pale brown cell at the apex and the base.

Culture characteristics - Conidia germinating on PDA within $24 \mathrm{~h}$. Germ tubes produced from basal cell. Colonies on PDA slow growing, reaching 10-15 mm diameter after one month at $25{ }^{\circ} \mathrm{C}$ in natural light, circular, matte, greyish-green with hyaline margin at the beginning, becoming dark brown in the inner circle, dark brown and pale brown in the middle ring, with hyaline sparse hyphae in the outer ring on the surface, with entire margin, dark brown in reverse. Sporulation absent. Vegetative hyphae are formed hyaline to mid brown, globose to ellipsoidal cells 5-12 $\mu \mathrm{m}$ diam., thick-walled, arranged in chains or moliniform.

Material examined - THAILAND, Phang Nga Province, Bann Tom Thong Khang, on decaying wood submerged in a freshwater stream, 17 December 2015, Kevin D. Hyde, Site 7-2-7 (MFLU 17-1973 holotype), ex-type living cultures, MFLUCC 16-0859, GZCC 17-0015.

Notes - Fuscosporella aquatica is the second species in the genus. Fuscosporella aquatica has larger conidiogenous cells $(17.5-44 \times 10-19 \mu \mathrm{m})$ and conidia $(38-60 \times 25.5-37 \mu \mathrm{m})$ compared to those in F. pyriformis (conidiogenous cells: 7.5-23 $\times 3.5-9 \mu \mathrm{m}$, conidia: $23.5-36 \times 14-21 \mu \mathrm{m}$ ) (Yang et al. 2016). Fuscosporella aquatica is also distinguished by its irregular ellipsoidal conidia, while $F$. pyrifomis has obovate to obpyriform conidia. Phylogenetic analyses revealed the separation of these two species in Fuscosporella. Additionally, the two-species showed multiple nucleotide differences between them for LSU and ITS gene regions respectively (Table 2). In the LSU region, they differ in seven nucleotides, in the ITS region, they differ in nine nucleotides which is line with the recommendations by Jeewon \& Hyde (2016).

Mucispora phangngaensis J. Yang \& K.D. Hyde, sp. nov.

Figs 3, 4

Index Fungorum number: IF553968, Facesoffungi number: FoF03864

Etymology - Referring to the collecting site from Phang Nga Province in Thailand.

Saprobic on decaying submerged twigs. Colonies on substrate sparse, scattered, glistening, black. Mycelium mostly immersed, consisting of septate, smooth, pale brown to hyaline hyphae. Conidiophores macronematous, mononematous, solitary, straight, erect, smooth, mid brown, paler towards the apex, 4-8-septate, $170-305 \times 5-7 \mu \mathrm{m}(\overline{\mathrm{x}}=245 \times 8.5 \mu \mathrm{m}, \mathrm{n}=20)$, truncate at the apex, with 1-2 percurrent proliferations. Conidiogenous cells monoblastic, integrated, terminal, cylindrical, pale brown. Conidia acrogenous, dark brown, ellipsoidal or obovoid, rarely pyriform, rounded at the apex and truncate at the base, 35-45 $\times 16.5-25 \mu \mathrm{m}(\overline{\mathrm{x}}=40 \times 20 \mu \mathrm{m}, \mathrm{n}=20)$, smooth, 3-euseptate, darkened at the upper two septa but unobservable when mature, with paler basal cell.

Culture characteristics - Conidia germinating on PDA within $24 \mathrm{~h}$. Germ tubes produced from basal cell. Colonies on PDA slow growing, reaching 5-10 mm diameter after one month at 25 ${ }^{\circ} \mathrm{C}$ in natural light, circular, with matte dark olivaceous and dense mycelium on the surface, dark in reverse with entire margin. Hyphae subhyaline to pale brown, sometimes constricted at the septa, 3-7 $\mu \mathrm{m}$ wide. Conidiophores reduced to a monoblastic conidiogenous cell. Conidiogenous cells 8 $10.5 \times 3.3-4.8 \mu \mathrm{m}$, integrated, subhyaline to pale brown. Conidia $23.5-47.5 \times 9.5-17.5 \mu \mathrm{m}(\overline{\mathrm{x}}=31$ $\times 14 \mu \mathrm{m}, \mathrm{n}=20$ ), pale brown to mid brown, 1-4-septate, mostly 2-septate, globose to obovoid, with cells becoming bigger towards apical cell, smooth, constricted at the septa.

Material examined - THAILAND, Phang Nga Province, Bann Tom Thong Khang, on decaying wood submerged in a freshwater stream, 17 December 2015, Kevin D. Hyde, Site 7-21-2 (MFLU 17-1974 holotype), ex-type living cultures, MFLUCC 16-0865, GZCC 17-0020.

Notes - Mucispora phangngaensis is the second species in the genus. It resembles Acrogenospora ellipsoidea D.M. Hu, L. Cai \& K.D. Hyde, Melanocephala triseptata (Shearer, J.L. Crane \& Miller) S. Hughes and Mucispora obscuriseptata in having cylindrical, percurrent proliferating conidiogenous cells, with dark brown, broadly ellipsoidal to obovoid conidia (Wu \& Zhuang 2005, Hu et al. 2010, Yang et al. 2016). Conidia in A. ellipsoidea are non-septate, while in Me. triseptata and Mucispora they are septate with obvious septa when young and obscured septa when mature. Mucispora obscuriseptata is distinguished from M. phangngaensis in having a 
Table 1 Isolates used in this study.

\begin{tabular}{|c|c|c|c|c|}
\hline \multirow[t]{2}{*}{ Species name } & \multirow{2}{*}{ Source } & \multicolumn{2}{|c|}{ GenBank numbers } & \multirow{2}{*}{ References } \\
\hline & & LSU & ITS & \\
\hline Adelosphaeria catenata & CBS 138679 & KT278707 & KT278721 & Réblová et al. 2016 \\
\hline Ascotaiwania fusiformis & MFLUCC 15-0621 & KX550893 & MG388215 & Yang et al. 2016 \\
\hline Ascotaiwania fusiformis & MFLUCC 15-0625 & KX550894 & MG388216 & Yang et al. 2016 \\
\hline Ascotaiwania mitriformis & HKUCC 3706 & AF132324 & - & Ranghoo et al. 1999 \\
\hline Ascotaiwania sawadae & SS 00051 & HQ446363 & HQ446340 & Boonyuen et al. 2011 \\
\hline Bactrodesmiastrum monilioides & FMR 10756 & KF771879 & KF771878 & Hernández-Restrepo et al. 2015 \\
\hline Bactrodesmiastrum obovatum & FMR 6482 & FR870266 & FR870264 & Hernández-Restrepo et al. 2013 \\
\hline Bactrodesmiastrum pyriforme & FMR 10747 & FR870265 & FR870263 & Hernández-Restrepo et al. 2013 \\
\hline Bactrodesmiastrum pyriforme & FMR 11931 & HE646637 & HE646636 & Hernández-Restrepo et al. 2013 \\
\hline Brachysporiella setosa & HKUCC 3713 & AF132334 & - & Ranghoo et al. 1999 \\
\hline Canalisporium exiguum & SS 00809 & GQ390281 & GQ390296 & Sri-indrasutdhi et al. 2010 \\
\hline Canalisporium grenadoideum & BCC 20507 & GQ390267 & NR_111442 & Sri-indrasutdhi et al. 2010 \\
\hline Canalisporium pulchrum & SS 03982 & GQ390277 & GQ390292 & Sri-indrasutdhi et al. 2010 \\
\hline Conioscypha lignicola & CBS 335.93 & AY484513 & - & Réblová and Seifert 2004 \\
\hline Conioscypha minutispora & FMR 11245 & KF924559 & NR_137847 & Crous et al. 2014 \\
\hline Conioscypha peruviana & ILL 41202 & KF781539 & -- & Zelski et al. 2015 \\
\hline Conioscypha varia & CBS 113653 & AY484512 & - & Réblová \& Seifert 2004 \\
\hline Fuscosporella aquatica & MFLUCC 16-0859 & MG388209 & MG388212 & This study \\
\hline Fuscosporella pyriformis & MFLUCC 16-0570 & $\overline{\mathrm{KX} 550896}$ & $\underline{\overline{M G 388217}}$ & Yang et al. 2016 \\
\hline Helicoön farinosum & DAOM 241947 & JQ429230 & $\overline{\text { JQ429145 }}$ & Réblová et al. 2012 \\
\hline Leotia lubrica & AFTOL-ID 1 & AY544644 & DQ491484 & Lutzoni et al. 2004 \\
\hline Melanotrigonum ovale & CBS 138742 & KT278708 & KT278723 & Réblová et al. 2016 \\
\hline Melanotrigonum ovale & CBS 138743 & KT278709 & KT278724 & Réblová et al. 2016 \\
\hline Microglossum rufum & AFTOL-ID 1292 & DQ470981 & - & Spatafora et al. 2006 \\
\hline Mucispora obscuriseptata & MFLUCC 15-0618 & KX550892 & MG388218 & Yang et al. 2016 \\
\hline Mucispora phangngaensis & MFLUCC 16-0865 & MG388210 & MG388213 & This study \\
\hline Parafuscosporella moniliformis & MFLUCC 15-0626 & KX550895 & $\underline{\text { MG388219 }}$ & Yang et al. 2016 \\
\hline Parafuscosporella тисоsa & MFLUCC 16-0571 & $\underline{\text { MG388211 }}$ & $\overline{\text { MG388214 }}$ & This study \\
\hline Phaeoisaria fasciculata & CBS 127885 & $\overline{\text { KT278705 }}$ & $\overline{\text { KT278719 }}$ & Réblová et al. 2016 \\
\hline Phaeoisaria fasciculata & DAOM 230055 & KT278706 & KT278720 & Réblová et al. 2016 \\
\hline Phaeoisaria microspora & MFLUCC 16-0033 & MF167351 & MF671987 & Hyde et al. 2017 \\
\hline Phaeoisaria sedimenticola & CGMCC 3.14949 & JQ031561 & JQ074237 & Cheng et al. 2014 \\
\hline Phragmocephala stemphylioides & DAOM 673211 & KT278717 & KT278730 & Réblová et al. 2016 \\
\hline Plagiascoma frondosum & CBS 139031 & KT278713 & - & Réblová et al. 2016 \\
\hline Pleurotheciella centenaria & DAOM 229631 & JQ429234 & JQ429151 & Réblová et al. 2012 \\
\hline Pleurotheciella rivularia & CBS 125238 & JQ429232 & JQ429160 & Réblová et al. 2012 \\
\hline Pleurotheciella rivularia & CBS 125237 & JQ429233 & JQ429161 & Réblová et al. 2012 \\
\hline Pleurotheciella uniseptata & DAOM 673210 & KT278716 & KT278729 & Réblová et al. 2012 \\
\hline Pleurothecium floriforme & MFLUCC 15-0628 & KY697277 & KY697281 & Hyde et al. 2017 \\
\hline Pleurothecium recurvatum & CBS 131272 & JQ429237 & JQ429149 & Réblová et al. 2012 \\
\hline Pleurothecium recurvatum & CBS 138747 & KT278714 & KT278728 & Réblová et al. 2016 \\
\hline Pleurothecium semifecundum & CBS 131271 & JQ429240 & JQ429159 & Réblová et al. 2012 \\
\hline Pleurothecium semifecundum & CBS 131482 & JQ429239 & JQ429158 & Réblová et al. 2012 \\
\hline Pseudoascotaiwania persoonii & A57-14C & AY094190 & - & Campbell \& Shearer 2004 \\
\hline Pseudoascotaiwania persoonii & A57-14C & AY590295 & - & Campbell \& Shearer 2004 \\
\hline Savoryella longispora & SAT 00322 & HQ446380 & HQ446359 & Boonyuen et al. 2011 \\
\hline Savoryella paucispora & SAT 00866 & HQ446381 & HQ446360 & Boonyuen et al. 2011 \\
\hline Savoryella verrucosa & SS 00052 & HQ446374 & HQ446353 & Boonyuen et al. 2011 \\
\hline Sterigmatobotrys macrocarpa & PRM 915682 & GU017317 & JQ429153 & $\begin{array}{l}\text { Réblová and Seifert 2011, } \\
\text { Réblová et al. } 2012\end{array}$ \\
\hline Sterigmatobotrys macrocarpa & $\begin{array}{l}\text { DAOM } 230059= \\
\text { CBS } 113468\end{array}$ & GU017316 & JQ429154 & $\begin{array}{l}\text { Réblová \& Seifert 2011, Réblová } \\
\text { et al. } 2012\end{array}$ \\
\hline Taeniolella rudis & DAOM 229838 & JQ429241 & JQ429152 & Réblová et al. 2012 \\
\hline
\end{tabular}

Newly generated sequences are marked in underlined bold font, new species are indicated in red bold.

Table 2 Polymorphic nucleotide in the LSU and ITS regions for Fuscosporella aquatica and $F$. pyrifomis.

\begin{tabular}{|c|c|c|c|c|c|c|c|c|c|c|c|c|c|c|c|c|}
\hline \multirow[t]{2}{*}{ Species } & \multicolumn{7}{|c|}{ LSU } & \multicolumn{9}{|c|}{ ITS } \\
\hline & 4 & 98 & 210 & 471 & 487 & 562 & 650 & 71 & 109 & 121 & 386 & 434 & 435 & 463 & 515 & 558 \\
\hline F. aquatica & $\mathrm{A}$ & $\mathrm{C}$ & G & $\mathrm{T}$ & $\mathrm{T}$ & $\mathrm{T}$ & G & $\mathrm{T}$ & $\mathrm{T}$ & - & $\mathrm{T}$ & $\mathrm{A}$ & $\mathrm{T}$ & $\mathrm{A}$ & $\mathrm{C}$ & $\mathrm{T}$ \\
\hline F. pyriformis & $\mathrm{T}$ & $\mathrm{T}$ & $\mathrm{A}$ & $\mathrm{C}$ & $\mathrm{C}$ & $\mathrm{C}$ & $\mathrm{A}$ & $\mathrm{C}$ & $\mathrm{C}$ & $\mathrm{C}$ & $\mathrm{C}$ & $\mathrm{G}$ & $\mathrm{C}$ & $G$ & $\mathrm{~T}$ & $\mathrm{C}$ \\
\hline
\end{tabular}

Isolate in blue highlight is newly taxon, position of nucleotide is based on the sequence alignment of Fuscosporella aquatica and $F$. pyrifomis. 


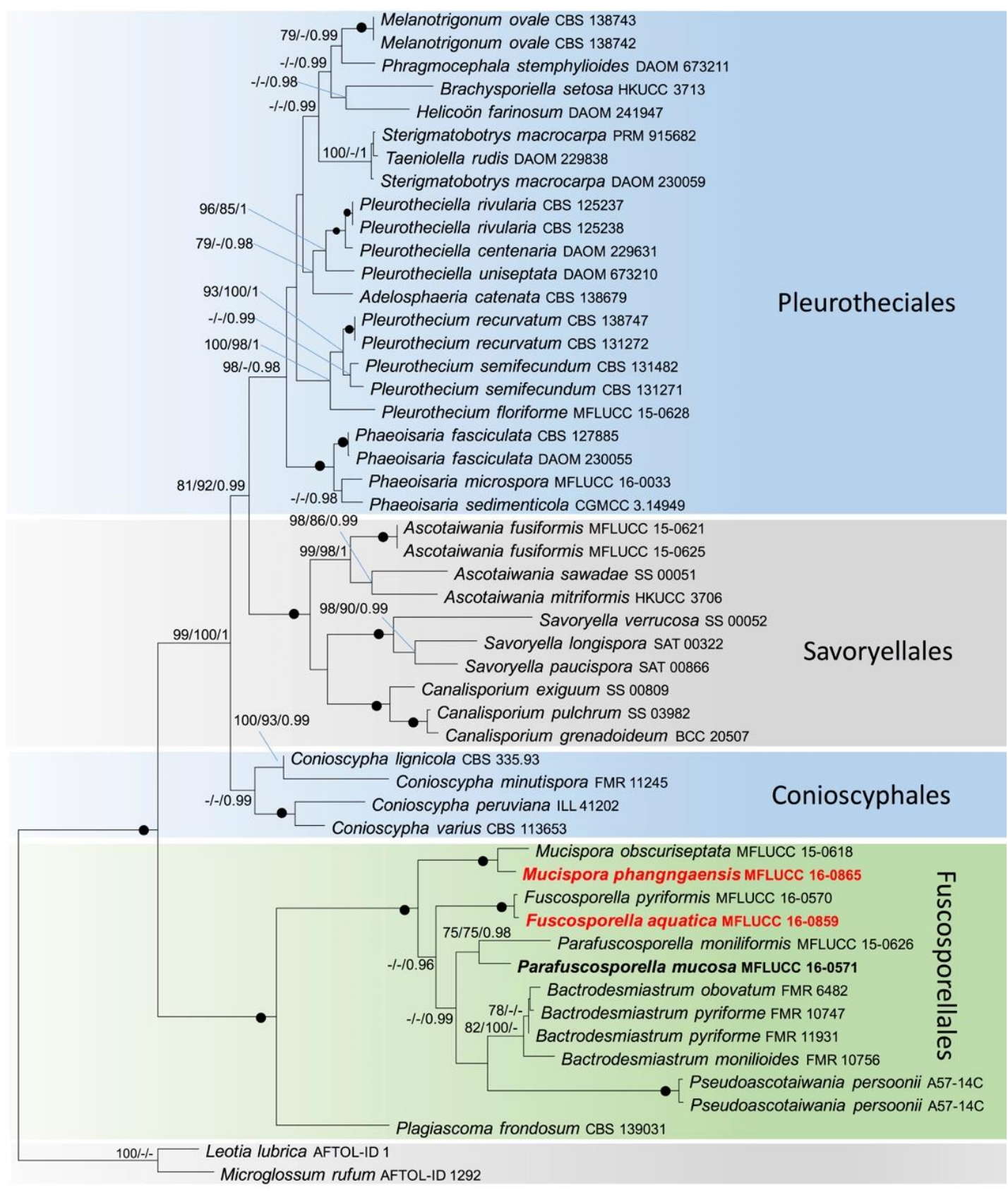

0.1

Figure 1 - Maximum likelihood majority rule consensus tree for the analyzed Hypocreomycetidae isolates based on a dataset of combined LSU and ITS sequence data. Bootstrap support values for maximum likelihood (ML) and maximum parsimony (MP) greater than $75 \%$ and Bayesian posterior probabilities greater than 0.95 are indicated above the nodes as MLBS/MPBS/PP. The scale bar represents the expected number of changes per site. The tree is rooted with Leotia lubrica and Microglossum rufum. The strain numbers are noted after the species names. The new strains are in red bold, newly generated strains are in black bold. Branches with 100\% ML BS, 100\% MP BS and 1.0 PP are shown as black nodes. Orders are indicated as coloured blocks.

conidial sheath. Melanocephala triseptata is distinctive with up to 10 proliferations. In addition, the conidiophores of Mucispora phangngaensis (170-305 $\mu \mathrm{m}$ long) are much longer than in $A$. ellipsoidea (87.5-162.5 $\mu \mathrm{m}$ long), Me. triseptata (100-250 $\mu \mathrm{m}$ long) and M. obscuriseptata (80$170 \mu \mathrm{m}$ long). The phylogenetic analyses also confirmed that Mucispora phangngaensis and $M$. obscuriseptata are phylogenetically distinct species. 
In this study, the second species in Fuscosporella and Mucispora are illustrated with morphological descriptions and phylogenetic support. Among the eleven taxa in Fuscosporellaceae, nine taxa are from aquatic habitats while two are terrestrial fungi. All the Fuscosporella, Mucispora and Parafuscosporella species were collected from freshwater habitats in Thailand. More detailed investigations may lead to the discovery of additional species in the order from Thailand or other countries.

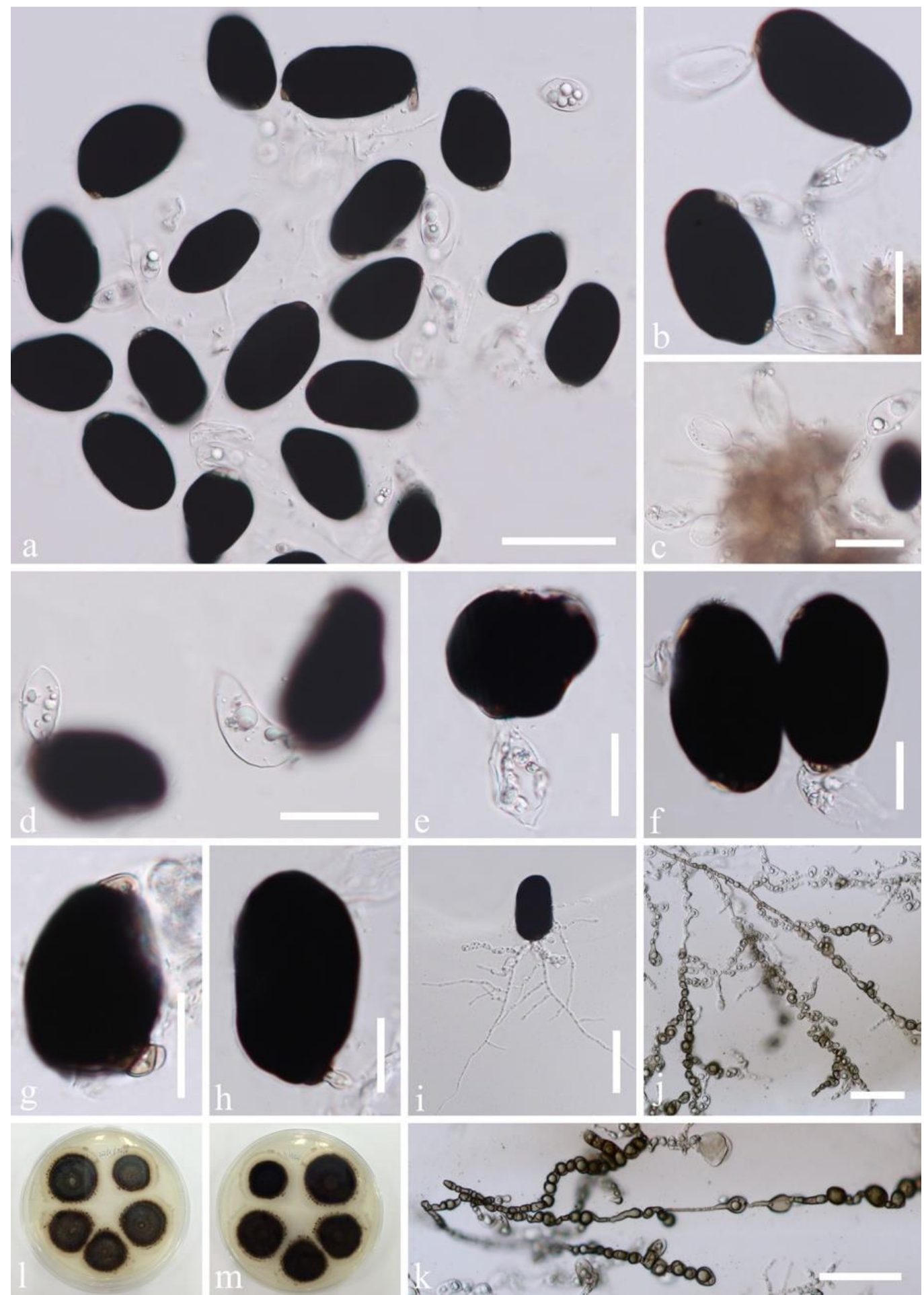

Figure 2 - Fuscosporella aquatica (MFLU 17-1973, holotype). a, g, h Conidia. b, c Conidiophores. $\mathrm{d}-\mathrm{f}$ Conidiogenous cells with conidia. i Germinated conidium on PDA medium. $\mathrm{j}, \mathrm{k}$ Hyphae on PDA medium. 1, m Culture, 1 from above, $\mathrm{m}$ from below. Scale bars $-\mathrm{a}, \mathrm{i}=50 \mu \mathrm{m}$, $\mathrm{b}-\mathrm{d}, \mathrm{j}, \mathrm{k}=30 \mu \mathrm{m}, \mathrm{e}-\mathrm{h}=20 \mu \mathrm{m}$. 

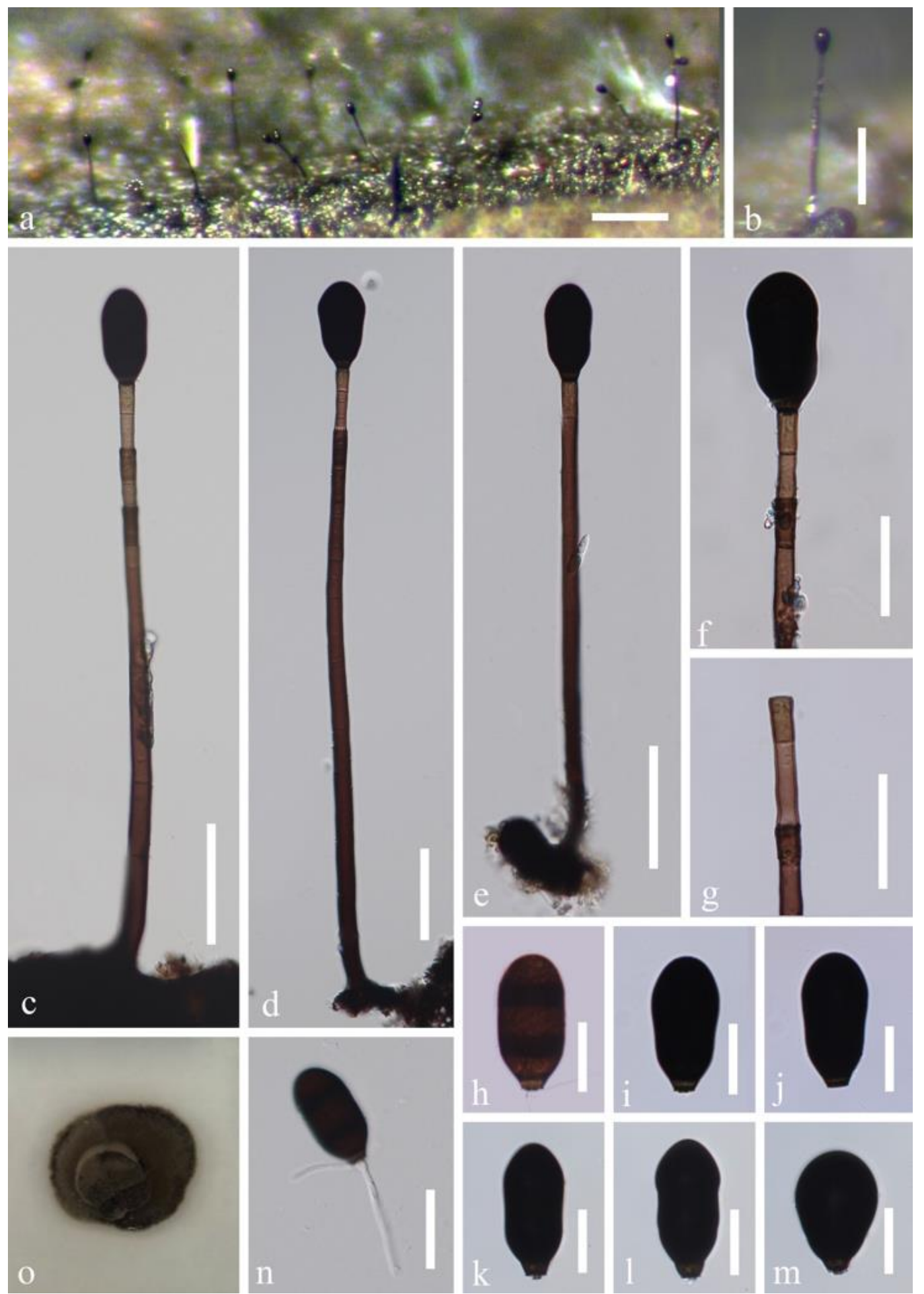

Figure 3 - Mucispora phangngaensis (MFLU 17-1974, holotype) a, b Colony on submerged wood. $\mathrm{c}-\mathrm{e}$ Conidiophores with conidia. f Close up of the proliferation. $\mathrm{g}$ Apex of the conidiophore. $\mathrm{h}-\mathrm{m}$ Conidia. $n$ Germinated conidium on PDA. o Culture from above. Scale bars $-a=200 \mu \mathrm{m}, \mathrm{b}=100$ $\mu \mathrm{m}, \mathrm{c}-\mathrm{e}=50 \mu \mathrm{m}, \mathrm{f}-\mathrm{g}, \mathrm{n}=30 \mu \mathrm{m}, \mathrm{h}-\mathrm{m}=20 \mu \mathrm{m}$. 

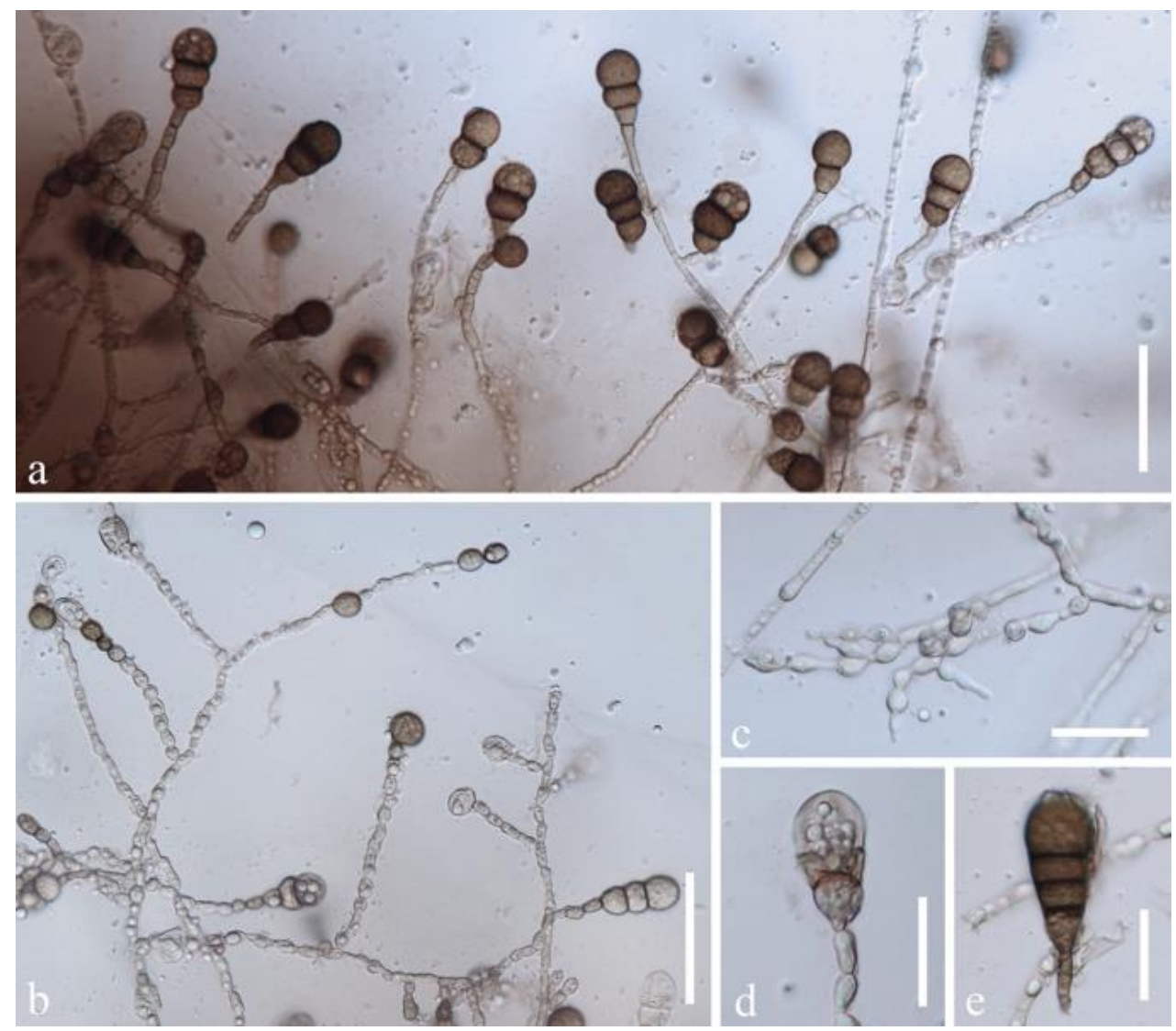

Figure 4 - Re-produced asexual morph of Mucispora phangngaensis on PDA medium. a, b Hyphae and conidia. $\mathrm{c}$ End of hyphae. $d$, e Conidia. Scale bars $-\mathrm{a}, \mathrm{b}=50 \mu \mathrm{m}, \mathrm{c}-\mathrm{e}=20 \mu \mathrm{m}$.

\section{Acknowledgements}

We would like to thank The Research of Featured Microbial Resources and Diversity Investigation in the Southwest Karst area (Project No. 2014FY120100) for its financial support. Jian-Kui Liu thanks Mae Fah Luang University (Chiang Rai, Thailand) for the offer of a short term Visiting Professorship in 2017.

\section{References}

Boonyuen N, Chuaseeharonnachai C, Suetrong S, Sri-Indrasutdhi V et al. 2011 - Savoryellales (Hypocreomycetidae, Sordariomycetes): a novel lineage of aquatic ascomycetes inferred from multiple-gene phylogenies of the genera Ascotaiwania, Ascothailandia, and Savoryella. Mycologia 103(6), 1351-1371.

Boonyuen N, Chuaseeharonnachai C, Suetrong S, Sujinda S et al. 2016 - Parafuscosporella garethii sp. nov. (Fuscosporellales) from a rivulet in a community-based northern forest, in Thailand. Mycosphere 7, 1265-1272.

Campbell J, Shearer C. 2004 - Annulusmagnus and Ascitendus, two new genera in the Annulatascaceae. Mycologia 96, 822-833.

Cheng XL, Li W, Zhang TY. 2014 - A new species of Phaeoisaria from intertidal marine sediment collected in Weihai, China. Mycotaxon 127, 17-24.

Chomnunti P, Hongsanan S, Aguirre-Hudson B, Tian Q et al. 2014 - The sooty moulds. Fungal Diversity 66, 1-36.

Crous PW, Shivas RG, Quaedvlieg W, van der Bank M et al. 2014 - Fungal Planet Description Sheets: 214-280. Persoonia 32, 184-306.

Goh TK, Hyde KD, Tsui KM. 1998 - The hyphomycete genus Acrogenospora, with two new species and two new combinations. Mycological Research 102, 1309-1315. 
Hillis DM, Bull JJ. 1993 - An empirical test of bootstrapping as a method for assessing confidence in phylogenetic analysis. Systematic Biology 42(2), 182.

$\mathrm{Hu}$ DM, Cai L, Chen H, Bahkali AH et al. 2010 - Four new freshwater fungi associated with submerged wood from Southwest Asia. Sydowia 62 (2), 191-203.

Huelsenbeck JP, Ronquist F. 2001 - MRBAYES: Bayesian inference of phylogenetic trees. Bioinformatics 17(8), 754-755.

Hughes SJ. 1979 - Relocation of species of Endophragmia auct. with notes on relevant generic names. New Zealand Journal of Botany 17, 139-188.

Hyde KD, Fryar S, Tian Q, Bahkali AH et al. 2016 Lignicolous freshwater fungialong a northsouth latitudinal gradient in the Asian/Australian region; can we predict the impact of global warming on biodiversity and function? Fungal Ecology 19, 190-200.

Hyde KD, Norphanphoun C, Abreu VP, Bazzicalupo A et al. 2017 - Fungal diversity notes 603708: taxonomic and phylogenetic notes on genera and species. Fungal Diversity 87, 1-235.

Index Fungorum. 2017 - available from: http://www.indexfungorum.org/.

Jayasiri SC, Hyde KD, Ariyawansa HA, Bhat DJ et al. 2015 - The faces of fungi database: fungal names linked with morphology, phylogeny and human impacts. Fungal Diversity 74(1), 3-18.

Jeewon R, Hyde KD. 2016 - Establishing species boundaries and new taxa among fungi: recommendations to resolve taxonomic ambiguities. Mycosphere 7(11), 1669-1677.

Katoh K, Standley DM. 2013 - Multiple sequence alignment software version 7: improvements in performance and usability. Molecular Biology and Evolution 30, 772-780.

Larget B, Simon DL. 1999 - Markov Chain Monte Carlo algorithms for the Bayesian analysis of phylogenetic trees. Molecular Biology and Evolution 16, 750-759.

Lutzoni F, Kauff F, Cox CJ, McLaughlin D et al. 2004 - Assembling the fungal tree of life: progress, classification, and evolution of subcellular traits. American Journal of Botany 91(10), 1446-1480.

Maharachchikumbura SSN, Hyde KD, Jones EBG, McKenzie EHC et al. 2016 - Families of Sordariomycetes. Fungal Diversity 79, 1-317.

Maharachchikumbura SSN, Hyde KD, Jones EBG, McKenzie EHC et al. 2015 - Towards a natural classification and backbone tree for Sordariomycetes. Fungal Diversity 72, 199-301.

Miller MA, Pfeiffer W, Schwartz T. 2010 - Creating the CIPRES Science Gateway for inference of large phylogenetic trees. In: Proceedings of the Gateway Computing Environments Workshop (GCE), 14 Nov 2010. New Orleans, LA 1-8.

Nylander J. 2008 - MrModeltest2 v. 2.3 (Program for selecting DNA substitution models using PAUP*). Evolutionary Biology Centre, Uppsala, Sweden.

Ranghoo VM, Hyde KD, Liew ECY, Spatafora JW. 1999 - Family placement of Ascotaiwania and Ascolacicola based on DNA sequences from the large subunit rRNA gene. Fungal Diversity 2, 159-168.

Rannala B, Yang Z. 1996 - Probability distribution of molecular evolutionary trees: a new method of phylogenetic inference. Journal of Molecular Evolution 43, 304-311.

Réblová M, Seifert KA. 2011 - Discovery of the teleomorph of the hyphomycete, Sterigmatobotrys macrocarpa, and epitypification of the genus to holomorphic status. Studies in Mycology 68, 193-202.

Réblová M, Seifert KA, Fournier J, Stepánek V. 2012 - Phylogenetic classification of Pleurothecium and Pleurotheciella gen. nov. and its dactylaria-like anamorph (Sordariomycetes) based on nuclear ribosomal and protein-coding genes. Mycologia 104(6), 1299-1314.

Réblová M, Seifert KA, Fournier J, Štěpánek V. 2016 - Newly recognised lineages of perithecial ascomycetes: the new orders Conioscyphales and Pleurotheciales. Persoonia 37, 57-81.

Réblová M, Seifert KA. 2004 - Conioscyphascus, a new ascomycetous genus for holomorphs with Conioscypha anamorphs. Studies in Mycology 50, 95-108. 
Sadowski E-M, Beimforde C, Gube M, Rikkinen J et al. 2012 - The anamorphic genus Monotosporella (Ascomycota) from Eocene amber and from modern Agathis resin. Fungal Biology 116, 1099-1110.

Spatafora JW, Sung GH, Johnson D, Hesse C et al. 2006 - A five-gene phylogeny of Pezizomycotina. Mycologia 98(6), 1018-1028.

Sri-indrasutdhi V, Boonyuen N, Suetrong S, Chuaseeharonnachai C et al. 2010 - Wood-inhabiting freshwater fungi from Thailand: Ascothailandia grenadoidia gen. et sp. nov., Canalisporium grenadoidia sp. nov. with a key to Canalisporium species (Sordariomycetes, Ascomycota). Mycoscience 51(6), 411-420.

Stamatakis A, Hoover P, Rougemont J. 2008 - A rapid bootstrap algorithm for the RAxML web servers. Systematic Biology 57, 758-771.

Stamatakis A. 2006 - RAxML-VI-HPC: maximum likelihood-based phylogenetic analyses with thousands of taxa and mixed models. Bioinformatics 22, 2688-2690.

White TJ, Bruns TD, Lee S, Taylor JW. 1990 - Amplification and direct sequencing of fungal ribosomal RNA genes for phylogenetics. In: PCR Protocols: A Guide to Methods and Applications (eds MA Innis, DH Gelfand, J Sninsky, TJ White). Academic Press, San Diego, 315-322.

Wu WP, Zhuang WY. 2005 - Sporidesmium, Endophragmiella and related genera from China. Fungal Diversity Research Series 15, 1-351.

Yang J, Maharachchikumbura SSN, Bhat DJ, Hyde KD et al. 2016 - Fuscosporellales, a new order of aquatic and terrestrial Hypocreomycetidae (Sordariomycetes). Cryptogamie Mycologie 37, 449-475.

Zelski SE, Raja HA, Miller AN, Shearer CA. 2015 - Conioscypha peruviana sp. nov., its phylogenetic placement based on 28S rRNA gene, and a report of Conioscypha gracilis comb. nov. from Peru. Mycoscience 56, 319-325.

Zhaxybayeva O, Gogarten JP. 2002 - Bootstrap, Bayesian probability and maximum likelihood mapping: exploring new tools for comparative genome analyses. BMC Genomics 3, 4. 